\title{
Modern Iranian Literature: The Historical and Present Development of the Short Story Genre
}

\author{
Oydin Turdiyeva \\ Tashkent State Institute of Oriental Studies, Tashkent, Uzbekistan
}

\begin{abstract}
The following article is about the historical overview of the Persian literature and the emergence and development of the short story as a literary genre and its prominent role in the modern literature of Iran. It discusses the origin of the short story in general and preconditions for the popularity of the new genre the Iranian literature of the 20th century, and also about the first successful collection of short stories that introduced it to the public. Also the development process of the short story and principle factors in every stage of its emergence as an independent genre of prose, as well as the thematic range are the main aspects among others to be analyzed in the article. It is historically documented that the Islamic state was established in 1979 after the fall of the Shah. And the very event had big impact not only on the social and political life of the country, but also on the cultural and literary life of the Iranians of the time. The significance of the revolution was such that it divided the literature to be known as the "pre-revolution" and "post-revolution" periods. Therefore this article is aimed to observe how this historic event had influenced the short story in particular and the distinct features of the works created during the two periods. The next period which stands out in the development of the short story is during the late 90 s and the beginning of the 2000, where the genre experienced aesthetic innovations and experiments with new forms and styles. The distinct feature of the period is mainly in its topics it deals, among other the effects of the globalization and popular culture brought forth, isolated individual, urbanization, climate change and its destructive outcome and the social conflicts resulting from them. Such global issues caused the established writers to look out of their borders and open up to the concerns of the planet, and by doing so establishing new schools of thought and style among the writers of short story in modern Iranian literature. Finally the article will overview the role of the Iranian contemporary female short story writers, children's literature and the works of the immigrant Iranian authors that continue the traditions of the Persian literature outside Iran.
\end{abstract}

Keywords: the short story, pre-revolution period, post-revolution literature, thematic range, female writers, immigrant authors, subgenre "داستانك", modernism school, children's literature

\section{Introduction: A Brief Look at History of Iranian Literature}

Described as one of the great and ancient literatures of mankind, Persian literature dates back as far as fifth century before Common Era and has been playing a significant role in the shaping of the world culture and

Oydin Turdiyeva, Senior Scientific Employee-Researcher at the Department of Literature of Foreign Eastern Countries, Tashkent State Institute of Oriental Studies. 
thinking. The Iranian land gave so many writers whose works, placed in the treasury of the world literature, still thrill the minds of the modern readers. Besides the impact they had on morality and spirituality in particular, and the human civilization in general, their masterpieces also helped to shape the literature into an art and science discipline.

Works of such great individuals as Ferdowsi, Nasir Khusraw, Omar Khayyam, Sa'di Shirazi, Hafez Shirazi, and Sana'i, Fariduddin Attar and Rumi (Maulana) who are renown as great poets and thinkers, have been for the generations of readers as the manuals for moral conduct, ideological imperative and philosophical reference for many centuries.

Significant place the classic Persian literature holds in world literary heritage can be seen by the lasting influence it had on the western literature and thinking. Especially it is obvious in the literature of the middle ages and Renaissance concerning the matters of the aesthetics and philosophy that was widely borrowed. Although the popularity of the tales, fables and the literary forms of the Persian origin, the names of the most "masters of pen" were little known in the West before the 18-19th century. The great German poet Goethe liked to stile himself as "Hafiz's apprentice", which resulted him publishing in 1819 his West-östlicher Divan, a collection of lyric poems inspired by a German translation of Hafiz (1326-1390).

But the most popular Persian poet in the 19th and early 20th centuries was Omar Khayyam (1048-1123), after his quatrain or Rubai collection was introduced to the Europe by Edward Fitzgerald's English translation in 1859, thus making Omar Khayyam one of the most quoted poets in English after Shakespeare. And Omar Khayyam has attracted a large following in the late 20th and early 21 st centuries after his works were rendered into the Russian language.

\section{Establishment of the Short Story Genre in Persian Literature}

While the enormous contribution of the classic Persian literature in the world literature is in the highest esteem among many literature historians and critics, the Persian-Iranian literature of the later period is mostly overlooked.

Short story writing takes its roots primarily from the folklore tales, ancient and classic forms of prose and story telling, and then due to its contact with the Arabic and European literature of the late 19th century.

In this period, the influence of the western literature on the Iranian writers and authors is obvious. The new and modern approaches to writing are introduced and several sub-genres have developed specially in the field of short story.

Up to the mid of the 19th century, prose was dominated by the traditional folk tales (hekayat), didactic stories (pandnome), fairy tales and historic and heroic sagas (ghessa).

The beginning of the 20th century is remarkable as a new period of radical change and modernization of the literature on a big scale, which opened the way for prose to explore new avenues of expression through which personal thoughts took on a more social overtone.

Some of the genres adopted during that period are still prominent in the modern Iranian prose, especially in a short story. 
Khamid Abdullakhiyon, ${ }^{1}$ Muhammad Huquqi, ${ }^{2}$ Jamal Mirsadiqi, ${ }^{3}$ Muhammad Kasimzade, ${ }^{4}$ Hasan Mirobidini $^{5}$ are the most notable literature scholars who dedicated their works on the history and analyze of the establishment and development of the short story genre in the modern Iranian literature.

Almost all the above-mentioned literature theorists agree on the same stages of the development that modern Persian short story undergone. It is divided into three periods: an establishment, formative period, a period of consolidation and growth, and a period of diversity. The formative period started in 1922 after the publication Mohammad Ali Jamalzadeh's collection "يكى بود و يكى نبود" (Yak-i Bud Yak-i Nabud-Once Upon a Time). This collection of short stories by Jamalzadeh (1895-1997) pioneered the genre in the Iranian prose and it gained its author the name of the "father of the modern Iranian literature".

Russian Orientalist K. Chaykin considers "Unce Upon a Time" as the first work of its kind to emplying the techniques of realistic writings and "... the Iranian literature shook off its shoulder the centuries old stories of mystic creatures, lofty and adorned expressions, and framed flowers, birds and butterflies, and at last dared to face with the reality of time" (Chaykin, 1928, pp. 144-145). ${ }^{6}$

The collection's narrative is pleasant and entertaining and it overflows with witty satire and light humor, mostly focusing on the political issues. It also laughs at the customs of the Persian society of the period, exposing to ridicule its backwardness and superstitions. ${ }^{7}$ His characters are often from them the common folk- simple, illiterate people. Jamalzadeh's prose is packed with colloquialisms and proverbial expressions, for he was among the first writers to abandon the ornate artificial style of traditional writing, making simple colloquial language the norm in modem Persian literature.

In this way, a new form of story telling emerged in the Iranian literature. And it went through consalidation and development in the framework of folklore, ancient and classical Persian literary heritage, and keeping up with the literary trends and achievements of Europe, especially France and other literature centres.

Creative writers quickly embraced this new brief fictional prose narrative. There were many admirers of short story thanks to its beautiful, lucid and simple language. Experimenting with short story resulted not only in invention of new forms and approaches, but also on the simplification of the Persian language of literature.

The reform-minded Iranian writers of the early 20th century addressed the works of the established writers of prose in Europe, North America and Russia and they looked for new models in their famous short stories. Among them Michelle Zhivago, Alexandre Dumas, Johann Wolfgang von Goethe, O. Henry, Anatole France, William Faulkner, Ernest Hamingway, Lord Byron, Victor Hugo, Charles Dickens, Honore de Balzac, Alexander Pushkin, Leo Tolstoy, Dostoyevsky, Chekhov, Gorky could provide with good models for characters, theme as well as style and plot.

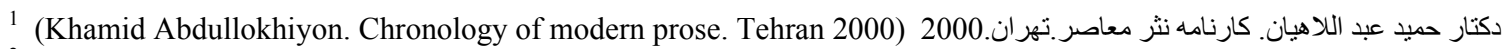

2 (Muhammad Huquqi. Overview: History of literature and modern Iranian literature. Tehran 1998)

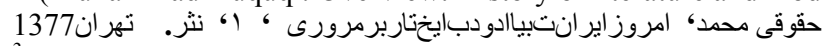

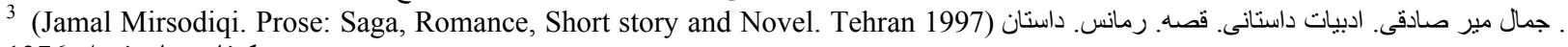

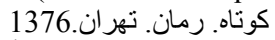

4 (Muhammad Kasimzada. Modern Iranian writers. Tehran 2004) 2004 محمد قاسمز اده. داستان نويسان معاصر اير ان. تهر ان

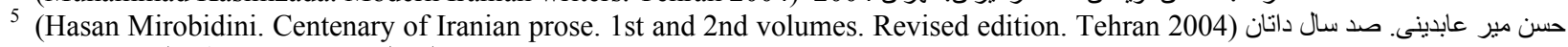
نويسى ايران. جلد اول و دوم با تجديد نظر كلى. تهران 1383

${ }_{7}$ K. Chaykin. Concise essay on the modern Persian literature. -M.: 1928, pp. 144-145.

7 idem. جمالز اده. يكى بود و يكى نبود .برلين. جإيخانه كاويانى. 1339 (1960)
} 
Inspired by the foreign classics of the genre, Iranian writers started observing the current order of things with critical eye and chose social issues as poverty, bribery, fornication, oppressed women, immorality and hypocrisy of the religious as their main topics.

\section{Characteristics of Short Stories in Pre-revolution Period}

From the start of the formative period until the period of diversity the short story genre comprise almost one hundred years. The path it passed began from didactic and educational stories, and later replaced by the realities of the contemporary social life. This kind of realistic stories became social and critical of tone. In the first period (1920s and 1930s) the thematic range was relatively small and this period focused on the predicaments of the little man, his or her daily concerns, issues, injustice by his or her senior, life in suburbs, dire state of peasants, women's emancipation, and so on. From 1930s and on the attention of the writers was drawn by new social and political issues, such as false elections, the tyranny and injustice of the ruling class. This period in the Iranian literature stands out as the most fruitful of changes and full of big names that were established. Among them were Bozorg Alavi, Jalal Ole-Ahmad, Muhammad Mas'ud Dehoti, Muhammad Hijazi, Sadeq Chubak, Behozin, Al'e Ahmad, and Sadeq Hedayat.

At this period short story that was newly introduced about two decades ago, has already gained ground in modern literature, kept evolving into the dominant genre of the prose. It also gained wide attention by different narrative style and techniques, with diverse range of themes and colloquial speech patterns that appealed to the middle class. Now for the first time in the history of Persian literature the short story left behind historical and social novels from the viewpoint of popularity and social resonance it had.

With the credit of pioneering of the genre still going to Jamalzadeh, the short story gained its momentum with the early short stories by Sadeq Hedayat (1903-1951).

Since short story prefers compact form, precise and clear language with economizing on every aspect of expression of the writer made it perfect medium for narrative, so it continued its dominant position in the Iranian prose of the 1940s and 1950s. The thematic range of the period was enriched with topics like patriotism, humanism, the hardships of an Iranian woman, fate of Iran's intellectual elite, suffering of the blue collar worker.

During the 1960s and 1970s growing national consciousness, formation of the new political and philosophical outlook among the learned was documented though the works of the writers of the time. Social discontent had been immediately transferred into the short stories in more detail, rather than in other form of the prose.

The works of progressive writers of the 1970s is mostly about the confrontation of the traditional values and culture mostly exported from the Western Europe and American, and as an outcome, big divide in the Iranian society. In this period backwardness and tragic lives of the poor, the Western influence to the social and cultural institutions, loss of national cultural identity were concern of that generation of writers. Popular culture spread further during the 1970s and its perceived pressure on the Iranian society to fall under the influence of the West was felt by every social strata. That is the reason behind the so-called monolithic colour that dominates in the palette of topics in prose over the whole 1970s. At the same time, the impact of ideas of national self-consciousness increased throughout the 1970s and awareness of contradictions between the prescribed traditions and the grim reality of modern man's life had become more widespread theme of the literature overall. 
Another characteristic of the pre-revolution period is its more liberal exchange of views in society, focus on the common values, moral and intellectual heritage of the human civilization, introduction to the classics of the world literature though extensive translation, as well as the call for the revival of the pre-Islamic cultural heritage of Persia. Also new cohort of writers employed a variety of approaches, from realism and naturalism to (myth and legend-like) surrealistic fantasy, breaking new ground and introducing a whole range of literary models and presenting new possibilities for the further development of the genre. All these factors contributed to the development of modem Persian fiction.

\section{Iranian Short Story in Post-revolution Period}

The third period in the development of modern prose, such as short-story coincides with the Revolution of 1979 , with its political purges and dramatic social upheavals. World history taught us that a political revolution immediately impacts the social order and that in turn leaves its mark on the thoughts of the writers and their works.

The period presented authors with new themes and topics. At first the most established Persian writers continued pursuing earlier social concerns, like drive for freedom of thought and speech, and of the press. And in the first few years after the revolution the modem Persian short story made considerable progress. And the revolution of the 1979 was no exception in transforming the contemporary literature completely. It is seen from the classification of the modern Iranian literature - dividing it into pre-revolution and post-revolution period, due the dramatic changes occurred thanks to the political change that it resulted.

Government of the Islamic Republic of Iran made it its priority to position culture and literature in a way to match the policy for religious and ethical matters and by doing so to strengthen the Islamic laws in the people's mind. $\left(\right.$ Klashtorina, 1990, p. 165) ${ }^{8}$

After the revolution, due to the political changes and censorship, some of the famous writers decided to leave the country and Iranian literature to some extent lost its initial vitality and strength. Although some literary talent left Iran, they managed to become inseparable part of the modern Iranian literature, and create a literature island of their own. That's literature of the Iranian Diaspora that had or chose to continue their work in the Western Europe and the US. The immigrant writers of that sort wrote in Persian, mostly about Iranian life and culture like before, with only an exception they lived and created their work outside of Iran.

The rest of the talented writers who chose to stay and adapt to the new political and social environment, focused on the changes the revolution brought, and the adversaries of the eight-year war with Iraq and its victims. However, what was common for the authors both inside the country and abroad, their main theme and concerns were around the Iranian society and its culture.

Most striking differences between the works of the two groups of the Iranian writer are-immigrant literature was free from any restraints that strict moral code and censorship inside the country put on the publications. They were more of an analytical and critical nature. On the contrary, the literature inside Iran had to serve as "a torch of moral and nationalism" in the hand of the state that could lead the nation out of the pre-revolution darkness towards the bright future ahead.

${ }^{8}$ V. B. Klashtorina. Iran of $1960 \mathrm{~s}-80$. From cultural pluralism to Islamisation of the moral values. P. 165. 
As we have observed in many societies on the transitional period, when the old traditions are denied and the new values are not established yet, the nation starts to look for the models of conduct and search for values in their ancient history and classic literature. One can observe the same process in the later period of the development of the Iranian literature. The literary trend in the Iranian literature of the 1980s was towards the centuries old Persian customs and traditional folklore, reviving and renovating the classical forms and themes. This new "introspection and imitation" took various shapes and approaches in different authors' prose.

Once again Iranian literature turned its face towards the revival of the Islamic values, ancient and classical prose forms, characters, symbolism, as well as satirical and didactic genres.

The new approach and interpretation of the ancient theme of the struggle between the Good and Evil was adopted by the short story writers of the 1980s. Most of the stories were staged during the times of the Shah's regime and highlighted the cruelty, political and social injustice among the society.

One of the classical genres that have been practiced for centuries is "munozara"-quiz, in the form of the question and answer exchange, and that has been very successfully revived in the modern Iranian literature of the time. For example: "And he said", "Then I said" are among the others that was modernized by applying the forms of the modern dialog. "He was out of the Earth" (او سماوى بود) by Zahro Zavoriyon and "Birthday" (روز تولد) by Mustafa Kheromon are one of the finest examples of the genre created in the 1990s. Another characteristic feature of the latest period is the traditional style of telling the story of everyday life using the symbolism techniques. Although in the classical Persian literature the same technique is found mainly in the riddles and fables, but the generation of the writers of the 1980s and 1990s started to employ it actively in their modern short stories. For example, a pine tree in A.Halili's "Beyond the pinewood" (آن سوى صنوبر ها) symbolizes existence and life, while the spring in the short story "Trip of the spring water" (سفر جشمه كوجى ) (سوى ) stands for the purity and freshness of mind.

Another classical genre that has found its way into the modern Iranian prose is "Pandname"-didactic stories with moral in the end told from the elderly to the youth. And we can find many pandnameh-like short stories in the works by A. Halili, B. Somoni, M. Bayrami et al.

Fables, myth and fairytales are among the most popular folklore genres that have never been abandoned due their appeal to the imagination of the common folk and children. Short stories such as "On Two Foxes" ( فسانه دو (دخاه (روباه) and "A Clever Girl" (ختر عاقل) by Mohamad Mirkiyani were written under the influence of traditional fairytales. Such kind of "fantastic" genres that are out of our harsh and logical reality, served as a perfect medium for conveying otherwise vulnerable writer's attitude to the readers about the pains and problems of the society.

\section{Thematic Range}

Analyzing the thematic of the prose and short stories in the 1990s we can see some distinct topics that were relatively new, however, they seem to occupy the the minds of society. They include the concerns of the relatively recent history, retrospective look at the political and social life as a whole. Those newcomers into the established thematic range during this period are the following:

(1) the overturn of the Shah's regime and the following revolution;

(2) criticism of the social life during the rein of the Shah;

(3) patriotism and nationalism. The topic itself is divided into another two: 
(a) the war between Iran and Iraq, heroic fight of the Iranian people, war chronicles; (b) Impact of the war on the Iranian society;

(4) a life-style of the minorities among the Iran's population.

Women's writing has played significant role in the process of the development of modern Persian literature, although it gained particular status in the 1980s and 1990s period. There were a great deal of variety both in the genres and themes employed by pioneering women writers of the time. Among the prominent names that brought fresh air into the modern Iranian prose are Simin Daneshvar, Sahrnur Porsipur, Fazoleh Alizadeh, Guli Tarakki and so on. They are the progressive generation of the Iranian female writers that followed the steps of their pre-revolution courageous predecessors.

Not surprisingly, one of the striking aspects of contemporary women's writing in Iran is the representation of domesticity and how women occupy and/or are socially and culturally conditioned to configure themselves in the space of the home and the nation. Another wave of the young and talented writers that started to publish after the 1980s is Manij Jankuli, Samira Aslanpur, Zahra Zavoriyan, Vajihe Ali Akbari Somoni, and Razia Tujjar.

In the Islamic society such as of Iran for centuries women represented the domesticity and they were socially and culturally conditioned to occupy themselves in the space of the home and family. That long-standing and accepted role of the women as a mother, housewife caused big controversy in the society. However, such changes were very logical and they were brought up by the political and social changes that occurred after the revolution. The modernizing attempts of the nation eventually opened up new spheres to women and made room for women's education and participation in public life.

Early works of the Iranian modern writing dealt with the domestic problems and their scope was confined into daily issues. Deeper understanding of the emotional state of the characters and depiction of the internal conflicts were primary goal in most of the short stories. Likewise, in the late 1990s the focus of the both male and female writers shifted on the analysis of the subconscious world of the characters, psychological and emotional side took over the surface plot-line.

The Iranian literature of the late 1990s and early 2000 started to experienced novice artistic and aesthetic changes in the short-story genre.

Once again the traditional folklore and legends elements took over the thematic landscape of the contemporary literature. "Surah" (سورن) by Simin Daneshvar, "Journey to Solomon's City" (برو) (بفر بهر سليمان) by Amuzadeh Halili, and "Fairy" (برى (آبى) by Khosrav Babakhani are the well-known titles that share that above-mentioned qualities. Such short-stories could veil the problems of child's labour, destruction of the eco-system, pollution into such beautiful depiction and characters.

In the experimented with new writing techniques, style and forms, such as disrupted chronology, non-linear or circular plots etc. Already one of the smallest literary prose forms, the short story kept shrinking evermore and special subgenre "داستانك" came into existence.

"Sunrise" (طلوع) and "Broken Images" (تصوير هاى شكسته) by Razia Tujjar, "Life of a Lady" and "Neighbors" (همسايه ها عا (ه) by Zoya Pirzad are among the stories that have got very concise and brief form.

The next period which stands out in the development of the short story is during the late 1990s and the beginning of the 2000, where the genre experienced aesthetic innovations and experimentation with new forms and styles. The distinct feature of the period is mainly in its topics it deals, among other the effects of the 
globalization and popular culture brought forth, isolated individual, urbanization, climate change and its destructive outcome and the social conflicts resulting from them. Such global issues caused the established writers to look out of their borders and open up to the concerns on the global scale, and by doing so the literature widened the horizons of imagination about the realities of the world outside.

New disposition of the Iranian authors enabled them to learn from various schools of modernism and adopt their best traditions that are "digestible" for the Iranian readership, and unaware of that establishing new schools of thought and style with their refreshed short stories. Therefore in the contemporary Iranian literature the dominance of the followers of the realistic school is often challenged by the followers of the modernism school.

With the obvious tendency towards the preference for subjective depiction of the characters over the objective, and exchange of the logical and deductive contemplation with the intuitive thinking, the shift to modernism is evident in the latest writings of devoted supporters of the realistic style such as Razia Tujjar, Vajihe Somoni, Firuz Zanuzi Jaloli, and Zoya Pirzad.

“Falling Yellows and Growing Greens" (ريزش زردها رويش سبز ها), “Salvation" (رهائ), "Hard to Save a

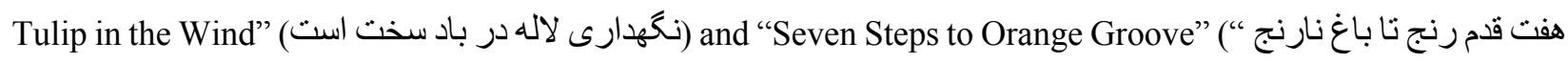
by Razia Tujjar, have all the elements of the modernism, taking place mostly in the surrealistic surroundings. Her short story titled "That Same Clear Voice" (آن صداى روشن) unfolds in the dream world full of hints, symbols, and mystic voices. Razia's another short story “Good night!” (آرن (آر شب به خبر) along with Vajihe Ali Akbar Samani’s “Last Stop" (ايستخاه آخر) uses fusion of the realism with elements of magic.

"Cursed Clock" (ساعت لعنتى) by Firuz Zanuzi Jalali is created depicting memorable psychological portraits through interim monologue and stream of consciousness techniques.

"Flying from an Abandoned Hill" by R. Tujjar and "Shadow of Horror" by Ahmad Ghulami are among post-modernistic prose, employing relatively new techniques like "pregnant" narrative, stream of consciousness, intuitive contemplation, as well as disrupted chronology and non-linear or circular plots. Some stories successfully employed non-linear plot along with fragmentary one, that is part of the narrative may seem logically detached from the rest of the picture and ignite inter-textual game in the minds of the readers.

\section{Iranian Diaspora}

Such novice approaches in the prose of the Iranian writers are observed in the works of the immigrant authors. Tarakki, Shahrnush Porsipur, Zoya Pirzad, Mahshid Amirshohi, Mahrnush Mazorei, Reza Daneshvar, Abbas Ma'rufi, Mahmud Masudi, Soson Qehraman, Reza Qasimi are the cohort of immigrant Iranian authors worthy of special notice.

Zoya Pirzad who lives and works in Germany is one of the renowned masters of the short story genre. Exact proportion of philosophical and lyrical thinking, psychology and drama along with lucid language in her short stories come from her deep knowledge of the literary traditions of the Eastern and Western classics. Although she chooses to depict relatively insignificant urban surroundings for her stories, she shows remarkable talent in creating vivid pictures that appeal to every person. Because themes of her works may depict Iranian society but they speak of universal values over traditional customs and prejudices. "Like All Other Afternoons" and "The Astringent Taste of Persimmon" are two collections of her short stories that brought her big acclaim among the modern Iranian authors. 
Mahshid Amirshahi is another well known writer, who lives in France. Her clear-cut and unadorned prose, delivered in laconic sentences and evocative language with a pinch of irony and humor earned her an instant fame after her first publications. Considerable parts of Amirsahi's stories are about childhood memories, conveying positive message and most characters just celebrate the life and they are written in an informal conversational style.

Mahrnush Mazorei is US-based Iranian writer who chooses to abandon an adorned language in favour of the plot and life event it depicts. Although her characters are mainly free but lonely depressed people, they constantly search for their inner self and meaning from their existence.

Such authors who live abroad keep contributing to the enrichment and diversification of the modern Iranian literature along with their peers inside the country.

\section{Children's Literature}

Another characteristic feature of the modern literature is writers' emphasis on the children's prose - both stories about and for children. Such literature is inseparable part of the Persian literature, didactic tales, fables and legends being one of the oldest and loved genres of all ages and of all times.

Children's literature in its pure form started to emerge during the era of "enlightenment". In the first half of the 20th century most of the works for children were rhymes, poems, fairytales and fables that prepared the ground for the further its development. Children's literature was especially gained momentum after the Islamic revolution and the next decade saw a wave of quality literary works about and for the youngest sector of the readers. During this period some writers realized their responsibility of raising and educating the new Iranian citizens, hence themselves becoming the guardians of the nation's spiritual core. They started to serve traditional values in more pleasant package for the young readers, buy depicting the struggle between the good and the evil in colorful and engaging ways, in fantastic habitats, using humor and action techniques.

Below are some topics that children's writers depicted in most of their short stories:

(1) child and nature;

(2) childhood hardships;

(3) friendship;

(4) education, school issues;

(5) suburban children and environment;

(6) funny stories and other topics.

\section{Conclusion}

In conclusion we can underline the importance of the turning point event that is the Islamic revolution that triggered the development of the Iranian literature and draw a clear line between the literature before and after 1979. The difference of the two periods is seen in the quality and quantity of the literary works, especially in the prose. Post-revolution literature prose becomes multidimensional both in style and in thematic range, with more positive approach to the social life, women starting showing active participation and children's segment to boost.

Despite the short stories for children are seen as a positive change, the literature about children and childhood memories is partly emerged because it could serve as a platform for some writers who opposed 
ideological restrictions and chose it to say their protest from the children's tongue.

Thanks to the advance of the information technologies and access to the mass-media, political affords to isolate the Iranian society practicing Islamic values, didn't gain full support. In the field of literature foreign literary trend and traditions managed to reach the writers inside Iran and enriched the Iranian literary landscape.

In the end of the 20th century and the beginning of the 21 st century humanity has come face to face with the concept of globalization that represented a move towards political, economical and cultural proximity and conformism.

Literature gained from the process by the global exchange of the ideas between the nations and local achievements learned internationally. And thanks to its strength and distinct voice, the Iranian literature managed to gain its due place in the world literature arena. This was possible because of the hard word of the talented writers who kept experimenting, challenging the established traditions, learning from the Persian classics.

Nowadays we can observe that in the short stories of the contemporary authors a person is depicted not as a mere demographic unity, a vehicle of social exchange and uniform workforce but as an individual with spiritual, traditional values, who has got a psychological world of conflicting needs and priorities. And it is the dominant way of looking at each their character among the contemporary Iranian writers. They also try to penetrate into the reality that makes the individual behave the way he does, employing new techniques of description and increasing the reach and appeal of the work.

The process in which how typical characters have been literally treated, depicted and evolved, can apply to the evolution of the Iranian prose as a whole. For over a century it has become more sophisticated and mature.

\section{References}

Chaykin, K. (1928). Concise essay on the modern Persian literature. Moscow: Universitet Trudyashchikhsya Vostoka Hasan, M.) صد سال داتان نويسى ايران. (Centenary of Iranian prose) (Vols. 1-2, Revised edition.). Tehran: Cheshmeh. Jamal, M. ادبيات داستانى. قصه. رمانس. داستان كوتاه. رمان. (Prose: Saga, romance, short story and novel). Tehran: Soxan. Khamid, A. (2000). كارنامه نثر معاصر .تهر انتان رمان (Chronology of modern prose). Tehran: Poyo.

Klashtorina, V. B. (1990). Iran of 1960s-80. From cultural pluralism to Islamisation of the moral values. Moscow: Nauka. Muhammad, H. مرورى بر تار يخ ادب و اد بيات امروز اير ان (Overview: History of literature and modern Iranian literature). Tehran: Qatre.

Muhammad, K. (2004) داستان نويسان معاصر ايران (Modern Iranian writers). Tehran: Hirmand. 